\title{
JULIO CÉSAR GOYES NARVÁEZ, DERIVAS ENTRE POÉTICAS
}

Julio Benavides 


\section{JULIO CÉSAR GOYES NARVÁEZ, DERIVAS ENTRE POÉTICAS}

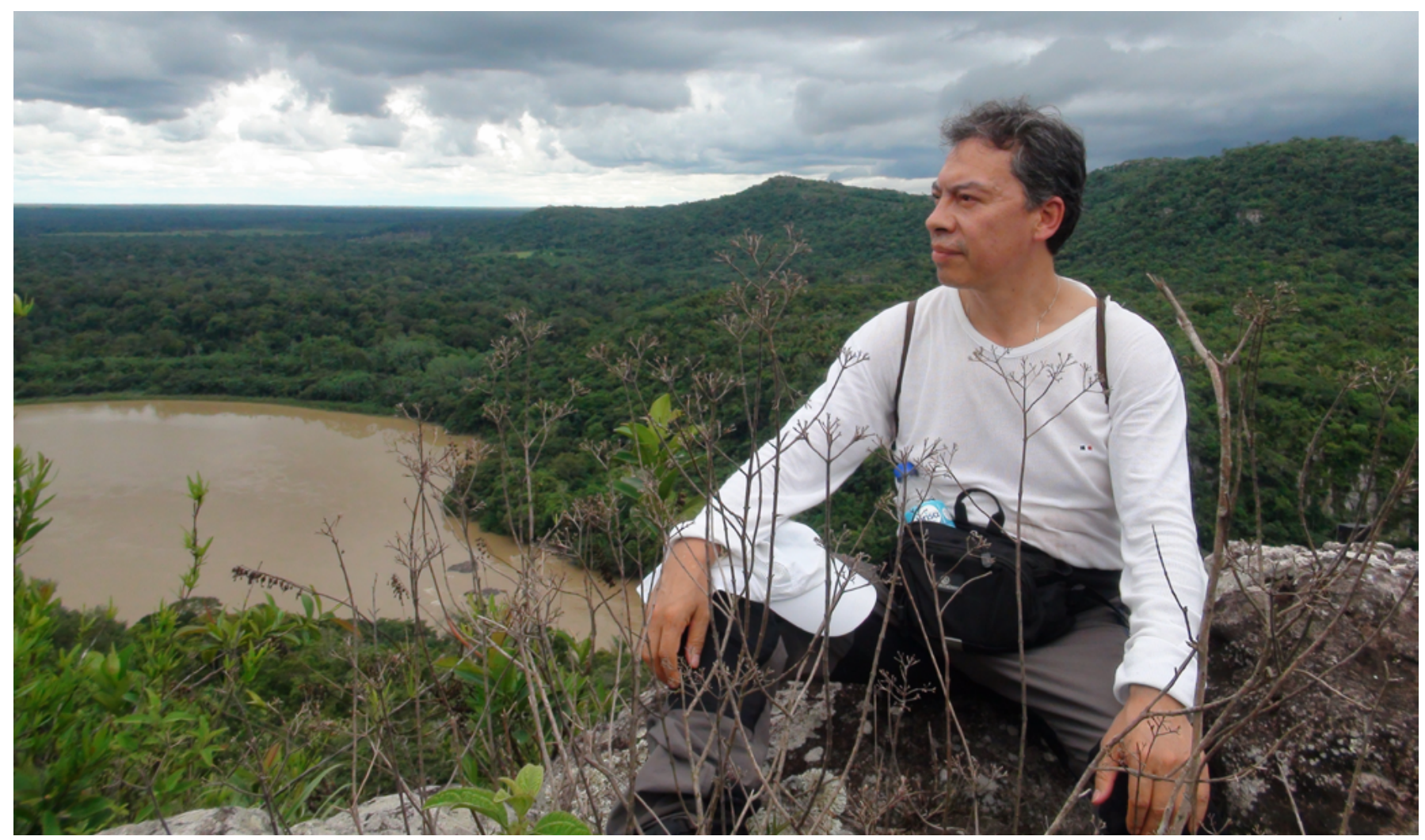

Julio César Goyes. Fuente: archivo personal

Durante la realización de la Ulibro 2017 nos acompañó el profesor Julio César Goyes Narváez, del Instituto de Estudios de Comunicación y Cultura de la Universidad Nacional de Colombia, quien estuvo presentando su reciente libro, "La mirada espejeante", un trabajo dedicado al desarrollo de la cinematografía del director ruso Andrei Tarkovsky, y a ofrecer una charla titulada "La investigación en comunicación como mediación creativa", en la cual planteó una forma de desarrollar la investigación-creación, a partir del desarrollo del proyecto "LEM Guaviare: leer y escribir con medios". Julio César es un nariñense que abrazó la poseía desde su infancia, en el propio ambiente familiar e innegable es la admiración que tiene por su paisano, el poeta Aurelio Arturo, quien fue inspiración para su labor como realizador audiovisual, con "Morada al Sur, la rapsodia de Aurelio Arturo". En su trayectoria se funden las letras con las imágenes, la oralidad y su fuerza para constituir memoria, para conmovernos a través de los relatos de la poesía y lo audiovisual. 
La T3RA: Bueno, Julio Cesar. Pues quiero que esto sea como una conversación, ya que tú lo planteaste en esos términos, tanto ayer, cuando presentaste tu libro, como hoy, al hacer tu exposición sobre la investigación en comunicación como mediación creativa. A partir de eso quiero preguntarte: ¿cuándo empieza tu interés por la imagen?

JCG: Yo pienso que viene con la poesía y esto estará en los orígenes de la constitución misma de mi infancia. Por el lado de la poesía oral; por el lado de mi padre, quien era un poeta oral, realmente. Era un lector; era un hombre humilde, pero no escribía. Había leído algunas cosas, pero, la poesía la tenía en la cabeza, ¿no? Sobre todo la de la vieja guardia, por ejemplo, Santos Chocano. Se sabía cada poema de memoria. José Asunción Silva, Julio Flórez, cosas así, de la vieja guardia, y él recitaba. Pero, además, yo nací y crecí en el contexto del "Carnaval de negros y blancos". Entonces, la imagen es muy poderosa, porque se articula con una materialidad, se vuelve muy comunal, ¿no?; de la comunidad del barrio (primero) y luego del mismo Ipiales en Nariño. Entonces, el carnaval es un texto que contiene otros textos: la oralidad, la poesía oral, el teatro, las artes plásticas, la música. Y, además, esto ya es nuevo, esta reflexión, porque vengo trabajando en ello, y he considerado que el "Carnaval de negros y blancos", en Nariño, es un carnaval cinematográfico. Va por las calles; sus carrozas, sus comparsas, sus trajes individuales, sus murgas de música, pasan frente a uno. Toda esa explosión de color y de expresiones, multiexpresiones, que es como pasar una película y además con relatos, fragmentos. Cada uno va planteándose algo distinto.

La T3RA: Bueno... partamos de ahí, quizás nos vamos mucho del caso específico, pero se trataría de una película que la hacemos año a año, pero una película que no siempre es igual a pesar de que es la misma película, ¿cierto?

JCG: Claro, sin duda. Es lo que yo decía en la conferencia acerca del colibrí o del quinde, la abejita hace lo mismo todo el tiempo, pero cada vez es diferente. Es otro color, es otra ruta, llega a otra flor, propone otro acto de polinización y eso, pues, cambia los libretos, digamos. Lo otro, es que no hay palabra sin imagen. $Y$ esto no es una preocupación tan original, sino que simplemente algunos lo evidenciamos un poco más, porque quizás encontramos en ella un lugar que antes no se veía para la investigación. Alguien quiere investigar la imagen, porque la imagen, entre otras cosas, no es lenguaje, y eso complica la investigación y la teoría, muchas cosas. Los semióticos trataron la imagen como lenguaje y resulta que la imagen no es lenguaje. Está con el lenguaje, que es distinto, pero no es lenguaje. Hace poco leí un libro en el que por primera vez que veo, en la introducción, que el investigador dice los lenguajes y la imagen.

La T3RA: A ver. Bueno... detengamos ahí porque me parece una cosa importante es decir... las imágenes incorporan a los lenguajes.

JCG: Son parte de ellos, claro, sí, incorporan, son parte de ellos.

La T3RA: Pero, cuando te refieres a que son dos cosas distintas, ¿te refieres en un sentido solo analítico o en un sentido, voy a decirlo de esta manera, más ontológico?

JCG: Tanto ontológico como analítico. Es que el problema de la imagen, y es ahí donde estamos abocados en este mundo, donde hay hiperindividualidad o hiperproducción de imágenes, es creer que la imagen carga 
ya en sí mismo el sentido. Nada. Hemos hecho pruebas. Se han hecho pruebas y podemos seguirlas haciendo. Si tú colocas una cámara en una esquina de Bucaramanga, en cualquier esquina de aquí, de la ciudad, y la dejas ahí todo un día, y luego recoges la cámara y te dedicas a ver imágenes, cosa que no lo hará uno, porque además eso produce una especie de estado esquizoide, ver una cantidad de imágenes impresionantes, sin saber qué, con gente que pasa. Eso lo hicieron los franceses, también; gente que pasa y que pasa y que pasa. Solamente le encuentras sentido cuando tú comienzas a seleccionar imágenes y comienzas a pegar y a montar, apuntarle un sentido de montaje y luego de edición, y entonces muestras lo que quieres y le das un sentido. Pero, solas no dicen nada. La imagen sola nunca dirá nada. Eso es interesante para las Ciencias humanas, porque el lenguaje tiene un espectro que, sin él, no podemos trabajar. Entonces los chicos tienen que aprender... bueno, no aprender, no, eso ya nos gusta, enseñar a aprender diríamos, pero aprendizaje, enseñar, si no, tiene que experienciar que sin el lenguaje no puede vivenciar las imágenes.

La T3RA: Cito, precisamente, textualmente, cuando hablas de Tarkovski, ya estamos haciendo un poco el salto a "La mirada espejeante", cuando te refieres a la intensidad de la experiencia, ¿sí? ¿Esa intensidad de la experiencia está en relación con la capacidad que tiene la imagen?

JCG: Sí... si me permites haría un "puentecito" antes.

LA T3RA: Sí, claro.

JCG: Creo que es clave, para llegar a esa pregunta tan interesante. Estaba pensando, por ejemplo, en Gérard Wajcman, un psicoanalista francés que tiene un libro que se llama "El ojo absoluto". Él habla, y esto lo he experienciado, he tenido esta experiencia en el edificio donde vivo, en el que hay cámaras para grabar. Entonces, se la pasan los vigilantes grabando todo el día y toda la noche. En mi edificio, por lo menos, pero yo sé que esto puede preguntarse en todas partes. Y pregunto: bueno ¿y tú, cuando estás por irte, revisas lo que grabaste? Nadie lo hace. Es terrible. Es terrible revisar 24 horas de imágenes, o sea, es esquizofrénico. Eso es muy importante, porque el ojo está en todas partes... y ya los japoneses lo están haciendo con ranas albinas, se las está mirando por dentro. Ya no tienes que diseccionar una rana, sino que la rana viva transparenta todo lo que tiene. Entonces es el ojo absoluto, es la vigilancia total. Solamente el lenguaje puede seleccionar todo eso y quitarnos ese sentido de que estamos vigilados y, además de eso, de que estamos fragmentados. Eso es interesante para los investigadores, porque hay que quitarle el predominio a la imagen, en el sentido de que es todopoderosa. Si no hay una historia, si no hay un trabajo sobre el relato y si no hay esa experiencia, de la que vamos a hablar enseguida... carambas, terminamos nosotros esquisos, que es lo que pasa con el zapping del televisor: todas las historias, pero ninguna.

LA T3RA: El ejemplo de las cámaras, el control y el registro, me ha hecho acordar del ejemplo de las cámaras que CityTv ponía en la entrada del canal y en la que las cámaras estaban ahí, pero solo grababan cuando alguien quería ser grabado, ¿si? y de alguna forma lo que uno veía es que, casi siempre, querían mostrar algo o querían mandarle un mensaje a alguien. $¿$ Es esa una manera de experienciar la imagen que uno sabe que va a ser difundida y no solamente se va a quedar en el registro de mi teléfono, sino que va a ser expuesta mediáticamente?

JCG: Claro, sí hay un tipo de experiencia desde mi 
punto de vista, pero no la experiencia desde su totalidad. Entre otras cosas todavía está la capsula, pero esa capsula es controlada, porque hasta ahora no he visto a alguien que se desnude ahí. Si hubiera eso, tal vez sería un estado de libertad interesante, pero, igualmente un contacto de choque muy fuerte en la comunicación. Entonces, ahí está controlada, hay digamos, lo que ya no hay montaje, pero hay edición. Se edita lo que la gente dice, porque hay gente que llega ahí, yo he estado ahí en El Tiempo muchas veces, llegan y dice vulgaridades, reclaman cosas, ultrajan al presidente, agreden al alcalde y eso no pasa a la emisión. Ahora para que la experiencia alcance su nivel tiene que ser experimental, más que experiencia. Se experimenta a ver cómo los públicos hablan para expresarse; para que llegue a la experiencia se necesita que se transporte un relato. El relato puede ser total simbólico o el relato puede ser meramente sígnico o, incluso, un relato quebrado de lo real. Los relatos de lo real son de violencia, sexo y muerte. Los noticieros los usan porque es lo más inmediato, causar impacto. Entonces mostrar el muerto, mostrar los problemas sexuales y mostrar los actos de violencia. Ahí el lenguaje no media ni es relato, es una constatación brutal del sujeto frente a lo real, pero lo real no significa.

LA T3RA: Pero a ver... por qué dices que el lenguaje no media si... por lo menos

JCG: ...Media

LA T3RA: Ah, media...

JCG: Media. Media, claro. Si no hay el lenguaje no, pero en lo real, cuando se muestra lo real no hay lenguaje. Ahí es donde volvemos a la imagen que no es lenguaje. $\mathrm{Si}$ un fotógrafo muestra un cuerpo que ha sido asesinado y no hay un pie de página, no hay una nota al lado, se constata como una nota brutal. Eso es lo que, por ejemplo, Lacan Ilamaba el ojo caníbal, que es absolutamente psicótico, no se explica nada con eso. Hasta el punto que los noticieros, por ejemplo, mostraban, bueno ahora ya se han relajado porque hay menos muertos o las cámaras no están llegando, mostraban las masacres de guerrillas y paramilitares y los espectadores almorzaban frente al televisor, hacían el amor frente al televisor, se saludaba uno frente al televisor y no pasaba nada. La imagen cuando es real y una constatación, se vuelve dato y ya no conmueve, y ese es el peligro de una sociedad así. Nos acostumbramos a la imagen de lo real, porque otra cosa es pasar de lo real a la realidad. La realidad sí es construcción, negociación de sentidos y de códigos.

LA T3RA: O sea estas refiriéndote a que hay un, digamos, hay un encuentro entre el lector y escritor.

JCG: Sí...

LA T3RA: Sí... cuando planteas que no pasa nada, de que yo puedo estar haciendo el amor mientras están transmitiendo por el televisor la masacre, es que no hay un encuentro entre quien está escribiendo, por decirlo de alguna manera, y quien está leyendo.

JCG: Es interesante lo que acabas de decir. Porque, claro, no hay un encuentro porque en ningún lugar, lo que está sucediendo allá no está nadie escribiendo. La escritura sí es una experiencia del relato, fuerte, simbólica. Entonces nadie está escribiendo, solo está constatando un dato, un dato que no me conmueve. Y está la sociedad del "lado de acá" que vive, y es grave, inmersa en una cultura que nunca se ha conmovido. Eso hablaba hoy en la ponencia de la compasión, de la pasión del otro, del dolor. Solo hay relato simbólico cuando el sujeto se quiebra, cuando el sujeto es capaz 
de llorar, de conmoverse, de sentirse de carne y hueso, de sufrir, y ese es el que está tratando de taparse, de velarse, porque la gente quiere más chistes... quiere más chiste. No la risa, que es otra cosa, ¿no?, quiere más chistes, más distracción, quiere más... ¿cómo es que se llama? Eso, quiere una televisión o un cine de diversión. Por eso Tarkovsky llega, porque Tarkovsky no te mete a la diversión, te mete en otro cuento. Lo que en psicoanálisis se llama el goce, no el placer sino el goce. El goce es que sientes placer, pero al mismo tiempo sufres.

\section{LA T3RA: ¿El goce es como una fruición?}

JCG: Sí, sí, algo así. Se podría traducir así. Psicoanalíticamente es el sujeto... es la construcción misma de la conciencia del sujeto, ¿no? Por ello, sabe que nace, pero, sabe que va a morir. Esta constatación lo lleva siempre a sacar placer del sufrimiento. Eso no es sadomasoquismo, aun cuando psicológicamente podríamos decirlo, pero es la constatación de todo ser humano en la historia de la humanidad. Somos eso, sentimos cierta satisfacción. Jesús Gonzales Requena dice: "no hay más violencia que el sexo, y sin embargo, lo repetimos".

LA T3RA: Que es un poco como dice Nietzsche en "El origen de la tragedia", cuando alude a lo creativo ligado al dolor, como el dolor del parto.

JCG: Sí claro, interesante, sí, es eso. Dar vida es un acto doloroso para la mujer. Por eso, cuando tiene su bebe lo considera su propiedad, hasta que muere. Si no hay padre, con palabra simbólica que separe estos dos cuerpos, se sentirán uno solo. Entonces este vínculo nacido del dolor también hay que separarlo, hay que sentir otra experiencia de dolor para que suceda el estado familiar de un relato... de una novela familiar, que arroje realmente un relato de esperanza o de futuro. Si no, no hay tal. Ahora, lo que pasa es que la imagen, y me parece que tu pregunta venia de allá también, en el caso de la imagen, por el lado de Tarkovsky y la imagen, -y yo pues eso lo dije ayer, aunque esas cosas no las puede decir uno en una conferencia sin desarrollarla-, se tiene que conocer la iconología rusa para entender porque no es representación sino iconostasis. Y eso es clave, porque nosotros acá tenemos la herencia occidental, de que todo para nosotros es representación, entonces, queremos siempre estar interpretando. Por ejemplo, gran parte de las investigaciones comunicativas lo dicen así, incluyendo los grandes investigadores latinoamericanos. Interpretar la realidad, asunto que viene de los filósofos modernos, ¿no?

LA T3RA: Es como en el caso del haiku, hay que entender la cultura japonesa para entender el haiku.

JCG: Sí, y no necesitas ser japonés, ¿no?, es lo que quiero decir, sino necesitas sentirte desde ese contexto y que es lo que te está diciendo. Entonces la iconostasis rusa y el haiku, porque entre otras cosas Tarkovsky fue un gran lector de haiku y se nota en el trabajo de la imagen -que denota haiku-, cuando la cámara se desentiende de los personajes, el director se va solo a hacer como su documental, como su obra artística y no le da ni miedo, al gran director como es él, hacerlo. Entonces el espectador queda un poco desubicado en sus historias. Por ejemplo: manda la cámara y se pone a ver ahí la pátina del tiempo en el paso de la naturaleza, como se ha descompuesto la naturaleza de un pozo; que en su infancia ese pozo fue de donde su mamá sacaba agua y lo tiene como recuerdo de niño. Y ahora lo ve, el pozo ahí está, pero está destruido, derruido, pero existe. Y ahí hay un haiku, pero, ahí hay una elaboración del lenguaje, o sea no del lenguaje hablado, sino del 
lenguaje no verbal, que a través de la imagen lo traspasa. Entonces la iconostasis de la iconología rusa es ver el pantocrátor, por ejemplo, o la Sagrada Familia de Rubliov; cuando los rusos ortodoxos ven eso están frente a lo sagrado, no están viendo que eso lo lleve a lo sagrado, no. Para ellos los pintores eran lo sagrado, algo que una cultura como la nuestra no puede entender. Para nosotros un pintor es el que pinta y no se va de la pintura. No. Allá Andréi Rubliov es el monje espiritual, es el gran maestro de los rusos, el que pintó su cuadro de la verdad, de la justicia, de la solidaridad de la bondad. Entonces van allí y están en una experiencia de lo sagrado.

LA T3RA: Si, me has hecho acordar de un acápite del texto "La guerra de las imágenes" de Serguei Gruzinski, cuando como desde la voz del indígena y frente a la furia del cura por algo que pasó -que en estos momentos no recuerdo-, agarra y se la emprende contra el crucifijo y lo tira al piso, y el indígena dice "está acabando con Dios" porque no es la representación de Dios, sino eso, en sí mismo, es Dios.

JCG: Claro, que lindo lo que dices, porque me parece muy interesante desde el punto de vista antropológico, porque nosotros nuestros pueblos tenían casi esa iconostasis, así no se llamara así, pero tenían una experiencia religiosa con las cosas que hacían, era directa. $Y$ por eso pudieron incorporar las versiones occidentales a sus versiones indígenas, en el caso de México, ¿no? incorpora a la virgen mexicana y la rodean de una penca, la rodean de cosas locales y le dan un sentido propio en un relato más complejo, inclusive, cosa que los europeos no podrían haber hecho. Por eso, porque la experiencia del relato, y ahora sí entramos relato, al lenguaje, es directa.

LA T3RA: A ver, volviendo, ¿es un poco como lo que ocurre en el "Carnaval de negros y blancos"?

JCG: Sí, que lindo. Claro, nosotros no tenemos una representación de sino una vivencia de. Uno no dice: uy que lindo eso que representa esa carroza, si fuera así todos tendríamos como un estado de académicos. Nadie dice eso. Se está viviendo el disfraz, se está viviendola "pintica", se está viviendola carroza, la música, la gente que pasa disfrazada. $Y$ eso, bueno, también lo dice Bajtin desde Rusia, tú no vas al carnaval como ir al teatro, a ir a ver una representación, tú vives el carnaval.

LA T3RA: No hay espectadores en el carnaval.

JCG: Claro, tú eres una performance, no estás ahí, dentro, como espectador. No, estás como carnavalero, jugando, porque tú eres parte del carnaval, así tú estés viendo una carroza. A eso se le llamaba en la medievalidad, teoría. Por ejemplo, una carroza es diciente de una teoría, porque es una propuesta de una visión de mundo.

LA T3RA: Sí, tengo entendido que además etimológicamente teoría y teatro están emparentados.

JCG: Sí, en ese sentido. En ese tipo de teatro, el carnaval se sale y rompe las paredes del teatro y es más existencia y vivencia, que otra cosa. No hay nada de representación allí, o sea, en el carnaval tú sales transformado y tú te comprometes. Corres el peligro de quedar atrapado en sus redes. En cambio en el teatro, en el cine o en la televisión, tú ves y no pasa nada contigo, tal vez se transforma algo dentro de ti, pero en un carnaval tú llegas a tu casa totalmente comprometido, transformado. $Y$ ese es el riesgo, entonces cuando yo hago eso, yo pienso en la investigación-creación, así. Tú vas a investigar y sales transformado. Sales con productos, pero con cosas, con 
textos. No es mentira, yo tengo ya un compadre en el Guaviare, o sea... ideas comprometidas. Corres ese riesgo.

LA T3RA: Bueno, eso es a lo que llamabas en tu conferencia "cartografía del territorio".

JCG: Sí, la cartografía es un pedazo, ¿no? yo lo retomo de Deleuze y Guattari, en "Mil mesetas. Capitalismo y esquizofrenia". A mí me gusta eso, pero es un pedacito, es un fragmento. Cartografía se puede llamar. Yo prefiero llamarle, de forma tradicional, metodología poético narrativa, pero cartografía suena académico, entonces suena "más bonito", digamos, ¿no? pero bueno no importa, etnografía narrativa, cartografía, investigación acción participativa; tantas modalidades, tantas técnicas, metodologías, que puedes aprovechar para hacer tu trabajo. Puedes llamarle como quieras. Lo importante es cómo tú sacas de ahí lo que quieres.

LA T3RA: Hablabas tú del lecto-escritor, retomando el proyecto de LEM Guaviare, pero subrayabas mucho el asunto de la oralidad. Cómo poner en compromiso, es decir estoy pensando en lo que tú planteabas, que uno tiene que responder a unas exigencias que están cifradas en un contrato que se hace con entes públicos, y uno dice, ¿la oralidad es algo que directamente puede, voy a decirlo de esta manera, transvasarse a lo escritural?, ¿no son dos cosas distintas y en ese sentido la oralidad tiene su propio lenguaje, tiene sus propias imágenes, frente a aquellas que recrea la escritura?

JCG: La memoria lo desarrolla de la mejor manera y ha sido siempre una preocupación mía. Y es que yo he venido constatando, bueno, no constatar... he venido experienciando y experimentando, también, varias cosas: que la oralidad y la imagen son cómplices, son hermanas, se interrelacionan muy fuerte y muy rápido y eso explica varias cosas: explica porque el pueblo latinoamericano fue educado más con la radio y más con los medios de comunicación, como el cine primero y luego la televisión, que con los libros. Eso es algo que le duele al lector, al bibliófilo, al que considere al libro como central en la constitución de la subjetividad moderna, y duele porque no le gusta pensar de esa manera. Pero, así sucedió. ¿Por qué? porque la oralidad y la imagen comparten varias psicodinámicas. Uno puede escoger a Walter Ong o a Paul Soukup o irse uno a constatarlo por sí mismo. Yo desde mi casa, como vengo de una familia humilde, la oralidad era más rápida para compartir el libro. Más relatos para compartir el libro. Entonces las investigaciones que están en varios de mis ensayos, yo las he puesto sobre la mesa, porque la oralidad como la que tenemos ahora en la entrevista es el tú a tú, el cara a cara, estamos muy rápido conectados, si nos equivocamos rectificamos, mientras yo hablo tú piensas lo que me vas a preguntar y mientras tú me preguntas yo pienso lo que voy a decirte. $Y$ es igual con la imagen, porque la imagen es un conjunto de emociones directas -sucede igual con Tarkovsky-, son psicodinámicas de expresión y de comunicación muy directas, muy rápidas. Conectan inmediatamente con los sentidos y con las consciencias, pero, iojo!, y aquí hay un problema central, que la palabra y la imagen llegan al inconsciente muy rápido, en cambio la escritura ataca más lo consciente y lo lógico. Y tú dirás, ¿pero qué pasa con la poesía?...pero, es que la poesía pudo incorporar, y bueno, la novela, incorporar la oralidad. Es como si supiera eso, digamos, es como si siempre se hubiera sabido que la oralidad se puede pasar por la escritura, a través del manejo de la lengua. Digámoslo rápido, de metáforas, de tropos, de ritmos, de puntuación. Yo no sé tú que sentiste cuando estaba leyendo, esta mañana, "La escritura de Orión"; la incorporación de la oralidad, pero, con la escritura. $Y$ haciendo énfasis en cada imagen, para que el pueb- 
lo guaviarense y amazónico entiendan qué es lo que estoy diciendo, pero dándoles otras palabras: comadre, fariña, todas esas palabras que vienen de las lenguas de ellos.

LA T3RA: Me preguntas eso y yo diría: es como la piel sensible de lo escrito. Como cuando tiene lugar la declamación. Eso es como yo lo sentí.

JCG: Bueno, no sé si haya declamación ahí, pero digamos que sí, hay una lectura más emocional, pero esa lectura emocional es una oralidad que pasa por la escritura. Y ahí está. Ahora, si yo no estoy el libro tiene que defenderse, porque la oralidad está inscrita en ritmo y en puntuación, y pasada por el habla. El habla es el que transporta, digamos, el inconsciente y la emocionalidad de la experiencia. Entonces estas dos cosas se confluyen y vas a cine y encuentras en muchas obras cinematográficas eso: la oralidad y la imagen. Ahora, no estoy diciendo para nada que la escritura está por fuera de eso. No, está incluida. Lo que pasa es que ya no tiene el valor o la valencia que tenía hasta hace poco en el mundo. Cuando pensábamos que solo podíamos aprender con el libro, pero, resulta que ahora, más que nunca, sabemos que un hombre oral, un viejo, un taita, un chamán, un payé, cuando nos hablan nos están pasando un conocimiento desbordante. Están haciéndolo, y aquí viene lo que yo le llamo escritura, también para poder desmarcarlo. Es una escritura, es una inscripción de la memoria, una escritura de la memoria. Que tiene que repetirse todo el tiempo, claro que lo es, al igual la escritura, él está pensando a la hora de poner una palabra tras la otra, para decirte lo que estoy haciendo yo ahorita. Entonces, es muy interesante.

LA T3RA: El caso extremo de la oralidad con forma de escritura serían los chats, que entre nosotros y entre la generación joven discurren por las redes, es decir, lo digo porque casi siempre esto es un objeto de crítica: es que sí, escriben mucho pero no, la ortografía; eso está lleno de emoticones, de símbolos que solo ellos entienden y eso no es escritura. ¿Sería eso un ejemplo de lo que puede ser, digamos, el límite, como en las matemáticas, el límite de la escritura ya vuelta totalmente oralidad?

JCG: No, yo no creo. Es otro tipo de oralidad y es secundaria, y además traspasada, en este caso, por la tecnología. Pero allí hay una oralidad que se está reinventando. Por ejemplo, ese es una fuente de investigación para nuestros comunicadores, y ya hay muchas investigaciones de esto, en Argentina y Brasil. Colombia apenas inicia, porque estamos ahora en la crítica, como siempre la crítica es la que nos demora tanto. Criticar todo lo que hacen los jóvenes, pero, no nos gastamos el tiempo comprendiéndolos. Eso es triste, a mí no me gusta pensar así. Yo trabajo con jóvenes y me enseñan mucho, me enseñan muchísimo de eso. iClaro!, hay errores, pero los errores vistos a la luz de nosotros, de nuestra generación. Como a la luz de nosotros veía la anterior generación, los errores que cometíamos con la escritura. Y allí está pasando mucho. Conozco el caso de un periodista, que es poeta, y lo mandaron a cubrir noticias en una región... no me acuerdo ahora si fue aquí en Santander o fue en Antioquia. Ahora mismo no me acuerdo. Y él estuvo en medio de los bombardeos y en medio de los tiroteos, y no podía hablar de los nervios, no podía trasmitir nada, entonces, se puso a hacer a través del Twitter a mandar frases; y se convirtió todo eso, todo lo que hizo ahí durante dos días en un libro de poemas. Porque las frases que él mandaba no podían ser contenidas por la racionalidad, sino por la experiencia desbordante de la muerte y de la violencia que estaban viviendo en el pueblo. Para mi es el ejemplo perfecto. Entonces, a 
través de frases -y después, las corrigió más-, llegaba por Twitter a sus compañeros, miles de personas que él tenía conectadas, inmediatamente, de una forma desbordante. Me parece que allí hay mucho que estudiar. La cantidad de estudios sobre cómo los jóvenes sí están, no haciendo otra oralidad, sino que están recreando un nuevo tipo de oralidad que ya no es la nuestra sino que están haciendo la de ellos, pero, la están pasado por la escritura. Entonces, la gramática, que es una norma -gramática entre otras cosas que es la teoría de la lengua, una gramática es una teoría de la lengua- y como nuestras academias son normativas, entonces, lo primero, es a corregirlos: no escribe bien el qué, lo apostrofan, las palabras no las dejan completas. iClaro! porque este es un mundo de la velocidad, de la fluidez. Un mundo de subjetividades, no de sujetos, sino subjetividades que circulan por las redes sociales... ¡Pues estudiémoslas! Y después de que las estudiamos decimos: no pues esto era una mentira, una ilusión, no sirve para la academia ni para la investigación. Pero no hay investigación en Colombia de eso, y si las hay en México, las hay en Europa. Y por ahí esta pasado mucha subjetividad de la juventud y la estamos desperdiciando. Tenemos mucho trabajo que hacer allí.

LA T3RA: Bueno, una última más que pregunta, porque hacerla es para responder teniendo una bola de cristal, has hablado de la imagen y de esa capacidad que tiene la imagen -digamos- de conmocionarnos, pero también has hablado de las imágenes que no nos tocan, que nos son totalmente -casi que- innocuas, ¿si? De las masacres o de las violencias que por televisión se muestran. En aras de pensar en el postacuerdo -me gusta más ese término que el de postconflicto-, ¿qué retos se presentan en términos del trabajo que comunicadores, artistas, escritores, en general todos los escribientes, tendrían que empezar a hacer?
JCG: Me gustaría dar un ejemplo colombiano de algo que se puede hacer, antes de contestar esa pregunta y completando la anterior. Si en los noticieros pasan todos esos sucesos violentos que no conmueven ya a la población, porque se repiten tanto dentro de contextos comerciales en los que después de ver una noticia de esas, tienes que ver la publicidad de objetos para vender y de músicas y de futbolistas y de deportes y todo eso. El trabajo que hizo el profesor Oscar Campo en la Universidad del Valle en la Escuela de Comunicación Social, y en el que pasó de ser documentalista a hacer su primera película de ficción, que se llama "Yo soy otro", que es la historia de José, un bogotano, ingeniero de sistemas que se va descomponiendo; vive en Cali y se va descomponiendo frente a todos estos sucesos de la historia nacional. Entonces lo que hace Óscar es mostrar al final, por varios momentos, mostrar las mismas imágenes de los noticieros. Y ahí, -bueno hay un ensayo mío que se llama "La huella de lo real" y se lo dediqué todo a Óscar-, es interesante, porque ahí sí conmueven todas esas imágenes $y$ en el noticiero no. Porque en la película de Óscar Campo hay un relato, hay un montaje, hay algo que contar. ¿Cómo un ser humano puede en Colombia resistir tanta violencia, tanta comunicación real sin mediación, sin una construcción del lenguaje creativo? Él sí lo hace. Y sale uno de la película absolutamente conmovido, aunque, claro, la película estuvo en cartelera y no duró ni 6 días. A la gente no le gusta ver lo que nos pasa, cuando se construye, realmente, como un relato conmovedor. Eso hay que investigarlo, o sea ya estamos 55 años en guerra o más, de guerra política, pero, también de guerra narcotráfico y otras violencias que nos tienen casi insensibilizados, digo yo. Ahora, conectemos con la idea que tú dices de... 
LA T3RA: ...De cómo los retos...

JCG: Los retos. Lo primero es dejar de dar consejos, yo veo eso y me preocupa, ¿no? Entonces, entrevistan a los gurús políticos, a los gurús de los diálogos, y, bueno, muchos de ellos son prudentes y no dan consejos. En el Guaviare eso es muy normal, que te pregunten: ¿qué consejos nos puedes dar? Sobre todo siendo un colono extranjero... No hay consejos para eso. Hay trabajos de investigación, hay libros, hay películas, radiografías.

Pero, sí sé por experiencia una cosa que es muy importante. No solamente, escuchar el relato del otro, por eso comencé con Manuel Levin, esta mañana, no es solo ver el relato del otro, sino escucharlo con responsabilidad, por un lado. Pero, no solo escucharlo. Es ir más allá. Uno termina haciendo su documental, pero no es suficiente. Hay que pasarles los medios, las plataformas tecnológicas de la información y la comunicación, a ellos. Son ellos los que tienen que contar y relatar. $Y$ cuando cuentan y relatan, y aquí hay un principio de la escritura contemporánea expandida que une la realidad y une la imagen, que es que cuando tú cuentas en plataforma multimedia, tú, en el mismo momento que empiezas a contar, caes en cuenta de lo que estás diciendo, de la forma y del contenido que transportas y descubres una cosa asombrosa -este es el sujeto del inconsciente en la enunciación-, descubres las posibles soluciones para esa experiencia. Los grupos focales dicen poco ya, porque no es ir a observarlos. Por ejemplo, en Nariño hemos recuperado la minga. ¡Hagamos minga! ¿Por qué tienen los doctores que sentarse allá, los magísteres allá, los licenciados más acá y nosotros, los que no hemos ido a la escuela, pues aquí para escucharlos? No, en la minga no tienes doctorado, ni eres magíster. En la minga puede ser de algún lugar, pero, aquí estas alrededor frente a la chagra, frente al fuego, frente a compartir un alimento y todos vamos a compartir, aquí, nuestra experiencia. Unas más largas, una más gordas, más robustas, más generosas y otras, menos robustas, pero potentes. $Y$ ahí vienen las soluciones a los conflictos de un proyecto social común, en el contexto en el que toca solucionar eso. Pero, ojo, esas soluciones de grupo humano hechas en Miraflores, no sirven para aplicárselas a Calamar, ni las de Calamar al Retorno San José, ni menos traérmelas para Bucaramanga y aplicarlas aquí. No hay tal. Por eso la investigación creación. Ir al contexto y mirar a ver que se puede hacer allá. Es un principio de humildad, yo creo. Nos toca quitarnos la aureola de investigadores y más bien ser guías, compañeros, una especie de turistas afectivos que se dejan permear por lo que ocurre, por la comida, por el calor, por la música que absorbe. Y eso no es fácil, porque te transforma, y si te dejas transformar, vas a cambiar tú primero y, luego, cambian los demás ayudándonos. Yo diría que es así.

Entrevista por: Julio Eduardo Benavides Docente investigador.

Facultad de Ciencias Sociales, Humanidades y Artes. Lider Grupo de Investigación Transdisciplinariedad, cultura y política. Universidad Autónoma de Bucaramanga Correo electrónico: jbenavides@unab.edu.co 
LA TERCERA ORILLA\#19, Diciembre 2017

153 